\title{
Chemical constituents from leaves of Avicennia lanata non ridley, Phamhoang (Avicenniaceae)
}

\author{
- Lam Phuc Khanh \\ - Huynh Khang Truc \\ - Nguyen Truong Thien Kim \\ - Nguyen Kim Phi Phung \\ University of Science, National University, VNU-HCM \\ - Nguyen Thi Hoai Thu \\ University of Medicine and Pharmacy of Ho Chi Minh City \\ (Manuscript received on March $20^{s t} 2012$, accepted on July $17^{\text {th }} 2013$ )
}

\section{ABSTRACT}

Avicennia lanata non Ridley, Phamhoang, Avicenniaceae widely grows in mangrove forests. There were some studies on plants of mangrove forests, and these results showed that they contained many interesting bioactive compounds. Nevertheless, Avicennia lanata has not yet been chemically and biologically studied in Viet Nam. From the hexane extract of the

leaves of Avicennia lanata, ursolic acid (1), lupeol (2), betulin (3), sitosterol (4), sitosterol 3-O- $\beta-D-$-glucopyranoside (5), and tectochrysin (6) were isolated. Their structures were identified by comparing their NMR data as well as physical properties with those in literatures. Further studies on this plant are in progress.

Key words: Avicenniaceae, Avicennia lanata, ursolic acid, lupeol, betulin, sitosterol, sitosterol 3-O- $\beta-D-$ glucopyranoside, tectochrysin.

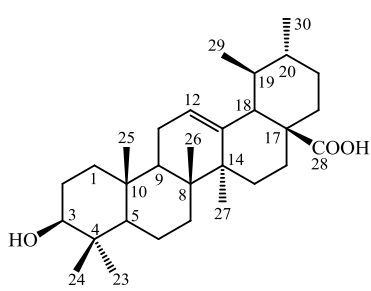

(1)

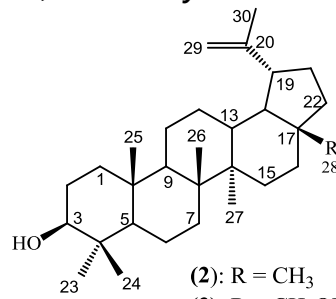

(3): $\mathrm{R}=\mathrm{CH}_{2} \mathrm{OH}$

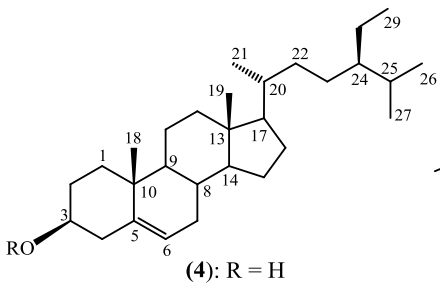

(5): $\mathrm{R}=\mathrm{Glu}$

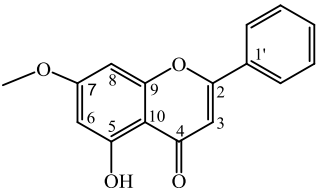

(6)
Avicennia lanata non Ridley, Phamhoang, Avicenniaceae (AL, Fig. 1) is also known as Avicennia marina var. rumphiana or Avicennia rumphiana Hall.f. [1]. This species wildly grows in many mangrove forests in Viet Nam. Stem of Avicennia marina has been traditionally used for the treatment of rheumatism, smallpox, ulcers [2]. Avicequinone-A and avicenol-A isolated from the dried aerial parts of Avicennia alba Blume and Avicennia rumphiana Hall.f. (Avicenniaceae) displayed remarkably inhibitory activities against Epstein-Barr virus early antigen activation in Raji cells without showing any cytotoxicity [3]. Furthermore, avicenol-A exhibited a good inhibitory effect on mouse skin tumor promotion in an in vivo two-stage

Trang 20 
carcinogenesis test. The result indicated the value as potent cancer chemopreventive agents of these naphthoquinones [3]. A number of compounds have been isolated from the plant under the name Avicennia marina [4] and Avicennia rumphiana Hall.f. [3]. Nevertheless, AL has not yet been studied in Viet Nam. In this paper, the isolation and structural determination of six compounds: ursolic acid (1), lupeol (2), betulin (3), sitosterol (4), sitosterol 3-O- $\beta$-D-glucopyranoside (5), and tectochrysin (6) were reported. Among them, (1), (2), (3), and (4) were already known in leaves of the Indian Avicennia officinalis [5] and (5) and (6) were isolated from this genus for the first time.

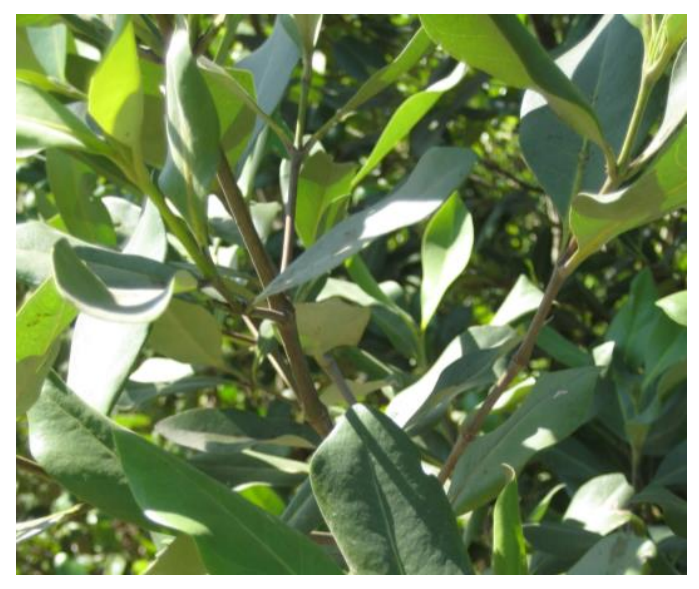

Figure 1. Avicennia lanata non Ridley, Phamhoang

\section{MATERIALS AND METHODS}

General: ${ }^{1} \mathrm{H}$ - and ${ }^{13} \mathrm{C}-\mathrm{NMR}$ were recorded on a Bruker Avance 500 (500 MHz for ${ }^{1} \mathrm{H}-\mathrm{NMR}$ and $125 \mathrm{MHz}$ for ${ }^{13} \mathrm{C}-\mathrm{NMR}$ ) in the Center of Analysis, University of Science, Vietnam National University - Ho Chi Minh City.

Plant materials: Fresh leaves of the plant were collected in Can Gio mangrove forest in Ho Chi Minh City, Viet Nam in February 2012. The scientific name of the plant was identified by Dr. Vo Van Chi. A voucher specimen (No US-B007) was deposited in the herbarium of the Department of Organic Chemistry, University of
Science, Vietnam National University - Ho Chi Minh City.

Extraction and isolation: Fresh leaves (40.0 $\mathrm{kg}$ ) were washed, dried, ground into powder $(15.0 \mathrm{~kg})$ and were extracted by percolation with methanol at room temperature then the methanol extract was evaporated in vacuum to give a methanol residue $(1.8 \mathrm{~kg})$. This crude extract was suspended in water with $10 \%$ of methanol, and was partitioned with hexane, ethyl acetate and then butanol. After evaporation at reduced pressure, four types of extracts were obtained: hexane $(200 \mathrm{~g})$, ethyl acetate $(220 \mathrm{~g})$, butanol $(180 \mathrm{~g})$, and methanol $(700 \mathrm{~g})$. The hexane residue was subjected to silica gel column chromatography (CC) (column: 120 x $6 \mathrm{~cm}$ ) eluting with a solvent system of hexane-ethyl acetate $(50: 1,9: 1,4: 1,1: 1,0: 1)$ and then ethyl acetate-methanol $(9: 1$ and $4: 1)$ to give eight fractions $\mathrm{HA}$ to $\mathrm{HH}$. The fraction $\mathrm{HG}$ (12 g) gave a precipitate which after washing with the methanol yielded 5 (100 mg). Applying the fraction $\mathrm{HB}(63 \mathrm{~g})$ to silica gel $\mathrm{CC}$, eluting with hexane-chloroform and then chloroform-ethyl acetate to afford eleven fractions HB1 to HB11. Compound $2(1.2 \mathrm{~g})$ was obtained from HB4 after rechromatography. The HB5 fraction was rechromatographed to afford $4(1 \mathrm{~g})$ and 6 (7 $\mathrm{mg})$. Compound 3 (0.8 g) was obtained from HB9. The fraction HC (15.8 g) was subjected to silica gel CC and eluted with hexane-chloroform (4:1) to give $1(1 \mathrm{~g})$.

Ursolic acid (1). Colourless amorphous powder, mp. $235-237^{\circ} \mathrm{C}\left(\mathrm{CHCl}_{3}: \mathrm{CH}_{3} \mathrm{OH}\right)$. The ${ }^{1} H-N M R$, pyridine $-d_{5}, \delta$ ppm: $3.43(1 \mathrm{H}, \mathrm{dd}, 10.0$; $6.0 \mathrm{~Hz}, \mathrm{H}-3), 5.46(1 \mathrm{H}, \mathrm{m}, \mathrm{H}-12), 2.61(1 \mathrm{H}, \mathrm{d}$, $11.5 \mathrm{~Hz}, \mathrm{H}-18), 1.20(3 \mathrm{H}, \mathrm{s}, \mathrm{H}-23), 0.87(3 \mathrm{H}, \mathrm{s}$, H-24), 1.03 (3H, s, H-25), 0.99 (3H, s, H-26), 1.21 (3H, s, H-27), 0.92 (3H, d, 6.0Hz, H-29), $0.97(3 \mathrm{H}, \mathrm{d}, 6.5 \mathrm{~Hz}, \mathrm{H}-30)$. The ${ }^{13} \mathrm{C}-\mathrm{NMR}$, pyridine $-d_{5}$, $\delta$ ppm: $39.8(\mathrm{C}-1), 28.5(\mathrm{C}-2), 78.6$ (C-3), 37.9 (C-4), 56.3 (C-5), 19.2 (C-6), 34.0 (C-7), 40.4 (C-8), 48.5 (C-9), 39.8 (C-10), 24.1 (C-11), 126.1 (C-12), 139.7 (C-13), 42.9 (C- 
14), 29.2 (C-15), 25.1 (C-16), 48.5 (C-17), 54.0 (C-18), 39.9 (C-19), 39.8 (C-20), 31.5 (C-21), 37.7 (C-22), 29.1 (C-23), 16.1 (C-24), 16.9 (C25), 17.9 (C-26), 24.3 (C-27), 180.2 (C-28), 17.9 (C-29), 21.8 (C-30).

Lupeol (2). Colourless amorphous powder, mp. $210-211^{\circ} \mathrm{C}\left(\mathrm{CHCl}_{3}\right)$. The ${ }^{l} \mathrm{H}-\mathrm{NMR}, \mathrm{CDCl}_{3}$, $\delta$ ppm: $3.18(1 \mathrm{H}, \mathrm{dd}, 11.5,5.0 \mathrm{~Hz}, \mathrm{H}-3), 2.37$ $(1 \mathrm{H}, \mathrm{td}, 11.0,5.5 \mathrm{~Hz}, \mathrm{H}-19), 0.97(3 \mathrm{H}, \mathrm{s}, \mathrm{H}-23)$, $0.76(3 \mathrm{H}, \mathrm{s}, \mathrm{H}-24), 0.83(3 \mathrm{H}, \mathrm{s}, \mathrm{H}-25), 1.03(3 \mathrm{H}$, s, H-26), 0.94 (3H, s, H-27), 0.79 (3H, s, H-28), $4.68(1 \mathrm{H}, \mathrm{d}, 2.0 \mathrm{~Hz}, \mathrm{H}-29 \mathrm{a}), 4.58(1 \mathrm{H}, \mathrm{dd}, 2.0$, $1.5 \mathrm{~Hz}, \mathrm{H}-29 \mathrm{~b}), 1.68(3 \mathrm{H}, \mathrm{s}, \mathrm{H}-30)$. The ${ }^{13} \mathrm{C}-$ NMR, $\mathrm{CDCl}_{3}, \delta$ ppm: $39.0(\mathrm{C}-1), 27.6(\mathrm{C}-2)$, 79.1 (C-3), 39.0 (C-4), 55.6 (C-5), 18.5 (C-6), 34.5 (C-7), 41.1 (C-8), 50.7 (C-9), 37.4 (C-10), 21.1 (C-11), 25.4 (C-12), 38.3 (C-13), 43.0 (C14), 27.6 (C-15), 35.7 (C-16), 43.2 (C-17), 48.6 (C-18), 48.2 (C-19), 151.1 (C-20), 30.1 (C-21), 40.2 (C-22), 28.2 (C-23), 15.5 (C-24), 16.3 (C25), 16.2 (C-26), 14.7 (C-27), 18.2 (C-28), 109.5 (C-29), 19.5 (C-30).

Betulin (3). Colourless amorphous powder, mp. $256-257{ }^{\circ} \mathrm{C}\left(\mathrm{CHCl}_{3}\right)$. The ${ }^{13} \mathrm{C}-\mathrm{NMR}, \mathrm{CDCl}$, S ppm: 38.7 (C-1), 27.4 (C-2), 79.0 (C-3), 38.9 (C-4), 55.3 (C-5), 18.3 (C-6), 34.0 (C-7), 41.0 (C-8), 50.4 (C-9), 37.2 (C-10), 20.9 (C-11), 25.3 (C-12), 37.3 (C-13), 42.7 (C-14), 27.1 (C15), 29.2 (C-16), 47.8 (C-17), 48.8 (C-18), 47.8 (C-19), 150.5 (C-20), 29.8 (C-21), 34.3 (C-22), 28.0 (C-23), 16.0 (C-24), 16.1 (C-25), 15.4 (C26), 14.8 (C-27), 60.6 (C-28), 109.7 (C-29), $19.1(\mathrm{C}-30)$.

Sitosterol (4). Colourless amorphous

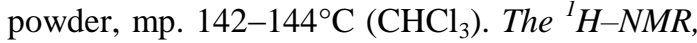
Acetone- $d_{6}, \delta$ ppm: $3.39(1 \mathrm{H}, \mathrm{m}, \mathrm{H}-3), 5.31(1 \mathrm{H}$, br, $\mathrm{H}-5), 1.02$ (3H, s, H-18), $0.72(3 \mathrm{H}, \mathrm{s}, \mathrm{H}-19)$, $0.96(3 \mathrm{H}, \mathrm{d}, 6.5, \mathrm{H}-21), 0.83(3 \mathrm{H}, \mathrm{d}, 7.0 \mathrm{~Hz}, \mathrm{H}-$ 26), $0.85(3 \mathrm{H}, \mathrm{d}, 7.0 \mathrm{~Hz}, \mathrm{H}-27), 0.86(3 \mathrm{H}, \mathrm{t}$, 7.5Hz, $\mathrm{H}-29)$. The ${ }^{13} \mathrm{C}-\mathrm{NMR}$, Acetone- $d_{6}, \delta$ ppm: $38.3(\mathrm{C}-1), 32.7$ (C-2), 71.8 (C-3), 43.4 (C-4), 124.5 (C-5), 121.6 (C-6), 32.9 (C-7), 32.6 (C8), 52.3 (C-9), 37.4 (C-10), 21.9 (C-11), 40.8
(C-12), 43.2 (C-13), 57.8 (C-14), 25.0 (C-15), 29.0 (C-16), 57.1 (C-17), 12.3 (C-18), 19.4 (C19), 37.0 (C-20), 19.3 (C-21), 34.8 (C-22), 27.0 (C-23), 46.9 (C-24), 30.3 (C-25), 20.1 (C-26), 19.8 (C-27), 23.9 (C-28), 12.3 (C-29).

Sitosterol 3-O- $\beta$-D-glucopyranoside (5). Colourless amorphous powder, mp. $290-292^{\circ} \mathrm{C}$ $\left(\mathrm{CH}_{3} \mathrm{OH}\right)$. The ${ }^{l} H-N M R, D M S O-d_{6}, \delta$ ppm: 5.31 $(1 \mathrm{H}, \mathrm{brd}, \mathrm{H}-5), 0.64(3 \mathrm{H}, \mathrm{s}, \mathrm{H}-18), 0.94(3 \mathrm{H}, \mathrm{s}$, $\mathrm{H}-19), 4.21\left(1 \mathrm{H}, \mathrm{d}, 8.0 \mathrm{~Hz}, \mathrm{H}-1\right.$ '). The ${ }^{13} \mathrm{C}-\mathrm{NMR}$, DMSO-d $d_{6}, \delta$ ppm: $36.8(\mathrm{C}-1), 29.2$ (C-2), 76.9 (C-3), 38.3 (C-4), $140.4(\mathrm{C}-5), 121.1(\mathrm{C}-6)$, 31.3 (C-7), 31.4 (C-8), 49.6 (C-9), 36.2 (C-10), 20.6 (C-11), 39.0 (C-12), 41.8 (C-13), 56.1 (C14), 23.8 (C-15), 27.7 (C-16), 55.4 (C-17), 11.6 (C-18), 19.0 (C-19), 35.4 (C-20), 18.6 (C-21), 33.3(C-22), 25.5 (C-23), 45.1 (C-24), 28.7 (C25), 19.7 (C-26), 18.9 (C-27), 22.6 (C-28), 11.7 (C-29), 100.8 (C-1'), 73.4 (C-2'), 76.8 (C-3'), 70.1 (C-4'), 76.9 (C-5'), 61.1 (C-6').

Tectochrysin (6). Colourless amorphous powder, mp. $165-166^{\circ} \mathrm{C}\left(\mathrm{CH}_{3} \mathrm{OH}\right)$. The ${ }^{l}{ }^{H}-$ NMR, $\mathrm{CDCl}_{3}, \delta$ ppm: $12.69(1 \mathrm{H}, \mathrm{s}, \mathrm{C} 5-\mathrm{O} \underline{\mathrm{H}}), 7.89$ (2H, m, H-2', H-6'), 7.53 (3H, m, H-3', H-4', $\mathrm{H}-5$ '), $6.69(1 \mathrm{H}, \mathrm{s}, \mathrm{H}-3), 6.38(1 \mathrm{H}, \mathrm{d}, 2.5 \mathrm{~Hz}, \mathrm{H}-$ 6), $6.52(1 \mathrm{H}, \mathrm{d}, 2.5 \mathrm{~Hz}, \mathrm{H}-8), 3.89(3 \mathrm{H}, \mathrm{s},-$ $\left.\mathrm{OCH}_{3}\right)$. The ${ }^{13} \mathrm{C}-\mathrm{NMR}, \mathrm{CDCl}_{3}$, $\delta$ ppm: $164.3(\mathrm{C}-$ 2), 106.1 (C-3), 182.5 (C-4), 162.5 (C-5), 98.4 (C-6), 165.9 (C-7), 92.9 (C-8), 158.1 (C-9), 105.9 (C-10), 131.6 (C-1'), 126.5 (C-2', C-6'), $129.3\left(\mathrm{C}-3^{\prime}, \mathrm{C}-5^{\prime}\right), 132.0\left(\mathrm{C}-4^{\prime}\right), 56.0\left(-\mathrm{OCH}_{3}\right)$.

\section{RESULTS AND DISCUSSIONS}

Compound 1 was isolated as white amorphous powder. The ${ }^{1} \mathrm{H}-\mathrm{NMR}$ spectrum showed an olefinic proton at $\delta_{\mathrm{H}} 5.46(1 \mathrm{H}, \mathrm{m}, \mathrm{H}-$ 12 ), an oxygenated methine proton at $\delta_{\mathrm{H}} 3.43$ $(1 \mathrm{H}, \mathrm{dd}, 10.0,6.0 \mathrm{~Hz}, \mathrm{H}-3)$. The ${ }^{1} \mathrm{H}-\mathrm{NMR}$ of 1 also displayed five singlet signals at $\delta_{\mathrm{H}} 1.20(3 \mathrm{H}$, $\mathrm{s}, \mathrm{H}-23), 0.87$ (3H, s, H-24), 1.03 (3H, s, H-25), 0.99 (3H, s, H-26), 1.21 (3H, s, H-27) for five tertiary methyl groups and two doublet signals at $0.92(3 \mathrm{H}, \mathrm{d}, 6.0 \mathrm{~Hz}, \mathrm{H}-29)$ and $0.97(3 \mathrm{H}, \mathrm{d}$, $6.5 \mathrm{~Hz}, \mathrm{H}-30$ ) for two other methyl groups. The

\section{Trang 22}


${ }^{13} \mathrm{C}-\mathrm{NMR}$ spectrum revealed thirty carbon signals. Among them, there were an olefinic quaternary carbon signal at $\delta_{\mathrm{C}} 139.7(\mathrm{C}-13)$, an olefinic methine carbon at $\delta_{\mathrm{C}} 126.1(\mathrm{C}-12)$, an oxygenated carbon at $\delta_{\mathrm{C}} 78.6(\mathrm{C}-3)$ and a carboxyl group at $\delta_{\mathrm{C}} 180.2(\mathrm{C}-28)$. The above information indicated 1 to be an ursane-type triterpenoid. From this information and by comparison with published data [6], 1 was identified as ursolic acid.

In the ${ }^{1} \mathrm{H}-\mathrm{NMR}$ spectrum of compound 2, the pair of signals at $\delta_{\mathrm{H}} 4.68(1 \mathrm{H}, \mathrm{d}, 2.5 \mathrm{~Hz}, \mathrm{H}-$ 29a) and $4.56(1 \mathrm{H}, \mathrm{dd}, 2.5,1.0 \mathrm{~Hz}, \mathrm{H}-29 \mathrm{~b})$ along with a singlet signal at $\delta_{\mathrm{H}} 1.68(3 \mathrm{H}, \mathrm{s}, \mathrm{H}-30)$ suggested the presence of an isopropenyl side chain. Besides that, there was a doublet of doublet signal at $\delta_{\mathrm{H}} 3.18(1 \mathrm{H}, \mathrm{dd}, 11.5,5.0 \mathrm{~Hz}$, $\mathrm{H}-3)$ in the downfield zone and six singlet methyl signals at $\delta_{\mathrm{H}} 0.76,0.79,0.83,0.94,0.97$, 1.03 in the highfield zone. The ${ }^{13} \mathrm{C}-\mathrm{NMR}$ spectrum displayed thirty carbon signals including two olefinic carbon signals at $\delta_{\mathrm{C}} 151.1$ (C-20) and 109.5 (C-29) of lupane-type triterpenoid, a signal at $\delta 79.2(\mathrm{O}-\underline{\mathrm{CH}})$ of oxygenated carbons $\mathrm{C}-3$ and twenty other carbon signals as usual. Therefore, the chemical structure of 2 was identified as lupeol by the comparison of its NMR data with the published ones ${ }^{[6]}$.

Compound 3 was a colourless amorphous powder. The ${ }^{13} \mathrm{C}-\mathrm{NMR}$ spectral data of 3 showed that it was also a triterpene with 30 signals like 2 . Two carbon signals of a disubstituted double bond at $\delta 109.7 \quad\left(=\mathrm{CH}_{2}\right)$ and $150.5 \quad(=\mathrm{C}<)$ supported 3 to be a lupane type triterpene. Besides an oxygenated methine group at 79.0 of C-3, 3 had another oxygenated methylene carbon signal at $\delta 60.6(\mathrm{C}-28)$. Comparison spectral data of 3 with those in literature [6] suggested that 3 was betulin (or lup-20(29)-ene-3 $\beta, 28$-diol).

The ${ }^{13} \mathrm{C}-\mathrm{NMR}$ spectrum of compound 4 showed many analogue signals as those of 5 such as two olefinic carbon signals of stigmastane-5- ene skeleton at $\delta 142.5(\mathrm{C}-5), 121.6(\mathrm{C}-6)$ in 4 and at $\delta 140.4(\mathrm{C}-5), 121.1(\mathrm{C}-6)$ in 5. However, 5 had one more anomeric carbon signal at $\delta$ 100.8 and five more oxygenated carbon signals from $\delta 76.9$ to 61.1 of a glucose unit. The anomeric proton signal at $\delta 4.21(1 \mathrm{H}, \mathrm{d}, 8.0 \mathrm{~Hz})$ determined the $\beta$ - orientation of the glucose. The comparison the NMR data of 4 with sitosterol [7] and of 5 with sitosterol $3-O-\beta-\mathrm{D}-$ glucopyranoside [8] showed well compatible. The structures of 4 and 5 were thus confirmed.

Compound 6 was isolated as white amorphous solid. The ${ }^{1} \mathrm{H}-\mathrm{NMR}$ of 6 showed two doublet protons at $\delta 6.38(1 \mathrm{H}, \mathrm{d}, 2.5 \mathrm{~Hz}, \mathrm{H}-6)$ and $6.52(1 \mathrm{H}, \mathrm{d}, 2.5 \mathrm{~Hz}, \mathrm{H}-8)$ located at meta positions. A singlet at $\delta 6.69$ was assigned to $\mathrm{H}-3$ while two multiplets at $\delta 7.53\left(3 \mathrm{H}, \mathrm{m}, \mathrm{H}-3^{\prime}, \mathrm{H}-\right.$ 4', H-5') and 7.89 (2H, m, H-2', H-6') belonged to protons of monosubstituted ring $\mathrm{B}$. A singlet signal was observed at a very low field zone $\delta$ $12.69(1 \mathrm{H}, \mathrm{s}, 5-\mathrm{OH})$ due to the formation of hydrogen bond between proton of the hydroxyl group and the carbonyl group $(\mathrm{C}=\mathrm{O})$ in the heterocyclic ring $\mathrm{C}$. A singlet proton signal at $\delta$ 3.89 was due to the presence of a methoxy group. Moreover, the ${ }^{13} \mathrm{C}$ and HSQC spectra showed the corresponded signals including a methoxy carbon signal at $\delta 56.0$, a signal at a very low region $(\delta$ 182.5 , C-4) which was definitive of carbonyl carbon of the flavone structure. Four oxygenated aromatic carbons were observed at $\delta 165.9(\mathrm{C}-7)$, $164.3(\mathrm{C}-2), 162.5(\mathrm{C}-5)$ and $158.1(\mathrm{C}-9)$. The rest aromatic carbon signals were observed from 140.0 to 92.9. The HMBC spectrum displayed a correlation between proton at $\delta 3.89$ and carbon at $\delta \quad 165.9$ which further confirmed the attachment of a methoxy group to $\mathrm{C}-7$. The HMBC spectrum also showed correlations of proton of hydroxyl group at $\mathrm{C}-5$ with carbons at 162.4 (C-5), 98.4 (C-6), and 105.9 (C-10). Comparison of the spectral data of 6 with those in the literature ${ }^{[9]}$ confirmed that 6 was tectochrysin. Tectochrysin displayed a high efficiency to chemosensitize transfected-cell 
growth to mitoxantrone at $1.0 \mu \mathrm{mol} / \mathrm{L}$. This flavone was therefore more potent to revert multidrug resistance, mediated by either wildtype or mutant ABCG2, than cytotoxic. Such characteristics of tectochrysin make it be good candidates for future clinical trials as potent and specific inhibitors of breast cancer resistance protein ABCG2 [10]. Tectochrysin possesses not only the anti-oxidant, but also the activities in $\mathrm{CCl}_{4}$-intoxicated rats. Especially, tectochrysin was found to cause significant increases in the rat liver the antioxidant enzymes including superoxide dismutase, glutathione peroxidase and indirectly glutathione reductase as well as a significant decrease in the malondialdehyde production [11].

\section{CONCLUSION}

From the fresh leaves of Avicennia lanata non Ridley, Phamhoang collected in Can Gio mangrove forest, ursolic acid (1), lupeol (2), betulin (3), sitosterol (4), sitosterol 3-O- $\beta-\mathrm{D}-$ glucopyranoside (5), and tectochrysin (6) were isolated. Further studies on this plant are in progress.

\title{
Thành phần hóa học của lá cây Mắm Quăn Acicennia lanata non ridley, Phamhoang, họ mắm (Avicenniaceae)
}

\author{
- Lâm Phục Khánh \\ - Huỳnh Kháng Trực \\ - Nguyễn Trường Thiên Kim \\ - Nguyễn Kim Phi Phụng \\ Trường Đại học Khoa Học Tụ Nhiên, ĐHQG- HCM \\ - Nguyễn Thị Hoài Thu \\ Đại học Y Dược TP HCM
}

\section{TÓM TÁT}

Cây Mắm Quăn phân bố rộng rãi ở các rừng ngập mặn. Mặc dù đã có khá nhiều nghiên cứu trên các cây ngập mặn, cây mắm quăn chưa được nghiên cứu nhiều trên thế giới. Ở Việt Nam, loài này chưa được tác giả nào khảo sát, nên cây mắm quăn được chọn làm đối tượng nghiên cứu của đề tài này. Từ cao hexan của lá cây mắm quăn, 6 hợp chất đã được cô lập gồm acid ursolic (1), lupeol (2), betulin (3), sitosterol (4),

sitosterol 3-O- $\beta-D-$ glucopyranoside (5) và tectochrysin (6). Cấu trúc hóa học của các hợp chất này được xác định dựa trên các phương pháp phổ nghiệm kết hợp so sánh với số liệu trong tài liệu tham khảo. Trong số sáu hợp chất trên, sitosterol $3-O-\beta-D-$ glucopyranoside (5) và tectochrysin (6) lần đầu tiên được biết có sự hiện diện trong chi Avicennia. Các nghiên cứu tiếp theo trên cây này vẫn đang được tiếp tục.

Tùr khóa: Avicenniaceae, Avicennia lanata, acid ursolic, lupeol, betulin, sitosterol, sitosterol 3 $O-\beta-D-$ glucopyranoside, tectochrysin. 


\section{REFERENCES}

[1] P.H. Ho, An illustrated flora of Vietnam, part III, Tre Publishing House, 845 (2003).

[2] W.M. Bandaranayake, Bioactivities, bioactive compounds and chemical constituents of mangrove plants, Wetlands Ecology and Management 10, 421-452 (2002).

[3] M. Itoigawa, C. Ito, H. T.-W. Tan, M. Okuda, H. Tokuda, H. Nishino, H. Furukawa, Cancer chemopreventive activity of naphthoquinones and their analogs from Avicennia plants, Cancer Letters 174, 135139 (2001).

[4] F. Zhu, X. Chen, Y. Yuan, M. Huang, H. Sun, W. Xiang, The chemical investigations of the mangrove plant Avicennia marina and its endophytes, The Open Natural Products Journal 2, 24-32 (2009).

[5] Ghosh, S. Misra, A.K. Dutta, A. Choudhury, Pentacyclic triterpenoids and sterols from seven species of mangrove, Phytochemistry 24, 1725-1727 (1985).

[6] S.B. Mahato, A.P. Kundu, 13C NMR Spectra of pentacyclic triterpenoids - A compilation and some salient features, Phytochemistry 37(6), 1517-1575 (1994).

[7] J. Goad, T. Akihisa, Analysis of sterols, Blackie Academic \& Professional, London, New York, Tokyo, 380-388 (1997).

[8] The Aldrich library of $13 \mathrm{C}$ and 1H-NMR spectra, Aldrich Chemical Company Inc, 440-449 (1993).

[9] K. Sutthanut, B. Sripanidkulchai, C. Yenjai, M. Jay, Simultaneous identification and quantitation of 11 flavonoid constituents in Kaempferia parviflora by gas chromatography, Journal of Chromatography A 1143, 227-233 (2007).

[10] A.A. Belkacem, A. Pozza, F.M. Martınez, S.E. Bates, S Castanys, F Gamarro, A D. Pietro, J.M.P. Victoria, Flavonoid structureactivity studies identify 6-prenylchrysin and tectochrysin as potent and specific inhibitors of breast cancer resistance protein ABCG2, Cancer Research 65(11), 4852-4860 (2005).

[11] S. Lee, K.S. Kim, Y. Park, K.H. Shin, B.K. Kim, In vivo anti-oxidant activities of tectochrysin, Archives of Pharmacal Research 126(1), 43-46 (2003). 